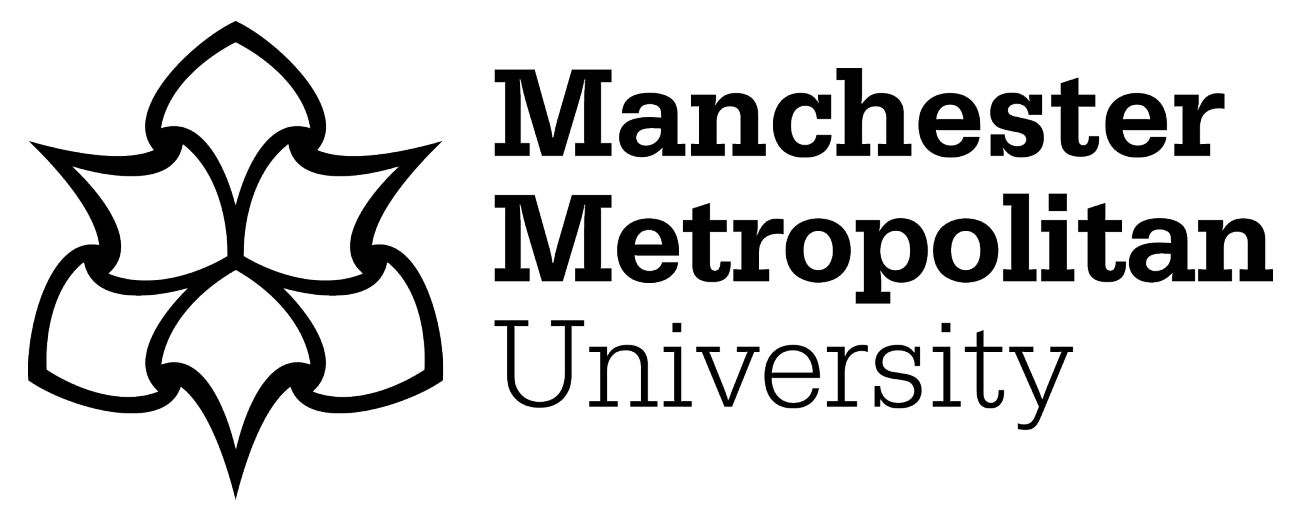

Kilcourse, Carl (2014) Son of God, brother of Jesus: Interpreting the theological claims of the Chinese revolutionary Hong Xiuquan. Studies in World Christianity, 20 (2). pp. 124-144. ISSN 1354-9901

Downloaded from: https://e-space.mmu.ac.uk/622197/

Version: Accepted Version

Publisher: Edinburgh University Press

DOI: https://doi.org/10.3366/swc.2014.0082

Please cite the published version 
Carl S. Kilcourse (C) 2014 Studies in World Christianity. This is the author's version of the work. The definitive version is published in Studies in World Christianity, vol. 20, no. 2 (2014), 124-44. http://dx.doi.org/10.3366/swc.2014.0082

\title{
Son of God, Brother of Jesus: Interpreting the Theological Claims of the Chinese Revolutionary Hong Xiuquan
}

Carl S. Kilcourse

\begin{abstract}
This paper examines the theological claims of Hong Xiuquan (1814-64), the leader of the Taiping Rebellion (1850-64). Whilst various aspects of the Taipings' theology and religious culture were characterised by originality, the most unique - and, for many, shocking - feature of their new theological worldview was the belief that Hong was the second son of God and younger brother of Jesus. This belief, which was based on visions that Hong had experienced in 1837, provoked criticism and condemnation from Protestant missionaries who were in China at the time of the Taiping Rebellion. The first part of this paper discusses two particular interpretations of Hong's claims in the reports of those missionaries. The analysis reveals that the missionaries' orthodox lens caused them to misunderstand and misrepresent Hong's claim to be the second son of God. Moving beyond the critical interpretations of the missionaries, the second part of this paper examines the Taipings' specific discourses on the nature of the Heavenly Father and his relation to Jesus and Hong. By analysing Hong's claims within this wider (and previously ignored) theological framework, the paper supports a new interpretation that views the title second son of God not as evidence of the Taipings' heterodox character, but as an access point for understanding their localised doctrine of God.
\end{abstract}

Keywords: Taiping, theology, localisation, Christianity, Confucianism, Shangdi, missionaries, China

This paper will examine the theological claims of Hong Xiuquan (1814-64), the leader of the Taiping Rebellion (1850-64). In 1837, after failing the civil service examination for a third time, Hong fell into a state of delirium and experienced a series of strange and (at that point) uninterpretable visions. ${ }^{1}$ When Hong failed for a fourth time in 1843 , he turned to a Christian book that he had obtained in 1836 (Liang Fa (1789-1855), Good Words to Admonish the Age (Quanshi liangyan; 1832)) and found in it an interpretation for his earlier visions and a new spiritual role for himself within the world. ${ }^{2}$ According to Hong's new interpretation, he ascended to heaven in 1837 and met the Heavenly Father (Tianfu) and the Heavenly Elder Brother (Tianxiong), Jesus Christ. ${ }^{3}$ The Heavenly Father (also known as the Great Shangdi, 'Supreme Lord/God') ordered Hong to expel evil demons from heaven, and then sent him 
back into the world to destroy the demons that were deluding the people of China. ${ }^{4}$ Hong emphasised the divine origin of his demon-slaying mission not only by claiming that God had granted him the title Heavenly King (Tianwang), but also by asserting that he - as the 'natural younger brother' (baodi) of Jesus - was the second son of God..$^{5}$ Those who accepted these claims believed that the Heavenly Father was intervening in history through his second son to eliminate the demonic forces (including idols, popular gods, and the ruling Qing dynasty (1644-1911)) that were suppressing the Chinese people's true spiritual consciousness. This foundational belief energised the Taipings from the start of their antiQing rebellion in 1850 to the fall of their Taiping Heavenly Kingdom (Taiping Tianguo) in 1864.

The idea that Hong was the second son of God and younger brother of Jesus is probably the most well-known, yet misunderstood, belief of the Taipings' theological worldview. Many Western writers - from the mid-nineteenth century to the present - have viewed that belief as evidence of the Taipings' heterodox or unchristian character. Some interpreters, such as Eugene Boardman, have simply denied that the Taipings were Christians, but others have argued that they 'distorted' the imported religion and created an unauthentic 'pseudo-Christianity'. ${ }^{6}$ Unsurprisingly, the earliest advocates of this widely accepted interpretation were Protestant missionaries who worked in China at the time of the Taiping Rebellion. Analysing arguments and assumptions in the reports of those missionaries, the first part of this paper will reveal that their orthodox lens caused them to misunderstand and misrepresent Hong's claim to be the second son of God. The second part, drawing on official publications and Hong's annotations to the Bible, will examine the Taipings' specific discourses on the nature of the Heavenly Father and his relation to Jesus and Hong. By analysing Hong's claims within this wider (and previously ignored) theological framework, the paper will support a new interpretation that views the title second son of God 
not as evidence of the Taipings' heterodox character, but as an access point for understanding their localised doctrine of God.

\section{An 'Imposter' and 'Anti-Christ': Missionary Reports on the Second Son of God}

The most regular reporters on the religious character of the Taipings were Protestant missionaries from Britain and the United States. Those missionaries were drawn to the Taipings because their new belief system seemed to owe its existence to a Protestant Christian book (Liang's Good Words) and a Chinese translation of the Bible (the Gützlaff version, which Hong received in 1847). The missionaries wanted to know how their religion had been received by the Taipings, if it had been altered in any significant way, and whether the rebels were willing to be instructed in gospel truth as they understood it. The Taipings' belief that Hong was the second son of God and younger brother of Jesus roused the missionaries' interest more than any other doctrine. The missionaries were divided on how exactly to interpret that belief, but they were united in their conviction that it was a blasphemous threat to orthodox truth.

For many of the missionaries who directly encountered the Taipings, the doctrine of God and his two sons stood out as the clearest sign of the rebels' deviation from Christian truth. The missionaries were most offended not by Hong's divine mission to destroy demons, but by the title son of God that he ascribed to himself. According to one group of missionaries, the title showed that Hong saw himself as the equal of Jesus, a belief that would threaten the Christological, Trinitarian and soteriological orthodoxies at the heart of their theological worldviews. As Alexander Wylie (1815-87), a member of the London Missionary Society (LMS), put it, 'The monstrous doctrine they have adopted of Hung-seu-tseuen being the second son of God, and on a par with Jesus Christ... is, I fear, a most serious obstacle to their humble reception of the truth as it is in Jesus. ${ }^{7}$ In a more aggressive criticism of the 
same doctrine, the English Methodist W. N. Hall (1829-78) described Hong as an 'imposter' and 'Anti-christ' who 'claims equality with Jesus' and 'is worshipped by his followers as equal to Christ' ${ }^{8}$ Some of the missionaries even claimed that Hong was incorporating himself into the Godhead as a fully divine son of God. As the American Baptist Issachar Jacox Roberts (1802-71) concluded following a fifteen-month stay in Nanjing, 'I believe him to be a crazy man... making himself equal with Jesus Christ, who, with God the Father, himself, and his own son, constitute one Lord over all!"9 A similar conclusion was expressed by the English Methodist Josiah Cox (1828-1906), who reported in his journal that the 'Heavenly King sets up himself, and is worshipped as Divine. ${ }^{, 10}$

According to these missionaries, the title second son of God exposed Hong's blasphemous attempt to claim ontological equality with Jesus and divine status for himself. This interpretation shows that the missionaries saw Hong's title - or the general idea of a second son of God - as an attack on their common orthodoxy. The missionaries believed that there could only be one son of God in order to protect both the Trinitarian concept of the deity (Father, Son and Holy Spirit) and the ontological uniqueness of Jesus as saviour of the world. If there were multiple sons of God as the Taipings claimed, then Jesus would no longer be the one-and-only God-man (fully divine and fully human) with the special ability to reconcile God and fallen humankind through his life, suffering, death and resurrection. ${ }^{11}$ Another son of God - in this case, Hong - could have theoretically acted as saviour of the world. Wylie, Hall, Roberts and Cox were thus rejecting what they saw as an intolerable challenge to the orthodox doctrines of God and salvation.

The analysis of this paper will reveal that the missionaries' orthodox lens caused them to misrepresent the Taipings' doctrine of God and their understanding of Hong's relation to the deity in particular. Having imposed their own theological assumptions (namely, that a son of God was necessarily divine) onto Hong's claim to be the second son of God, the 
missionaries concluded that he saw himself as a divine equal of Christ when in fact he acknowledged both his own non-divine nature and the superior status of his elder brother Jesus. The missionaries thus reported not the actual meaning of Hong's title for the Taipings, but their own fears about its theological implications. They did not realise that their fear of an ordinary human being claiming the identity of God was shared by Hong and his followers opposition to usurpers of God's position was actually one of the guiding principles of Taiping theology.

Another group of missionaries put forward an alternative interpretation of Hong's claim to be the second son of God. Rather than reading the claim as an affirmation of Hong's equality with Jesus and divine status, these missionaries interpreted the title son of God metaphorically: Hong believed that he and Jesus were both chosen by God to carry out divine missions, but he did not believe that they were sons of God in a literal sense. The reports of Joseph Edkins (1823-1905) and Griffith John (1831-1912), both of the LMS, offer the clearest articulations of this figurative interpretation. According to Edkins, the Taipings referred to Jesus and Hong as 'natural brothers' (tongbao dixiong) not to show that they were divine sons of God, but to emphasise the complementary missions that the Heavenly Father had given to them. As Edkins put it,

His [Hong's] views of the divine nature of Christ are imperfect... He regards Christ as the greatest of God's messengers, and himself as second only to him; and it is in this light that he believes himself to be brother of Christ and God's son. ${ }^{12}$

John likewise asserted that Hong's claim to be the brother of Jesus was based on his conviction that 'the Saviour is the greatest of God's messengers, and he himself the second' ${ }^{13}$ The title son of God that the Taipings applied to Jesus and Hong thus signified not their consubstantial relation to God (having the same divine nature as the Heavenly Father), but their unique identity as the two individuals who had been chosen by God to carry out divine missions in the world. This interpretation of the Taipings' claims about Jesus and 
Hong explains why other observers compared the religion of the rebels to Islam and Unitarianism. $^{14}$

From the figurative perspective of Edkins and John, the theological consequence of the title second son of God was not that it secured godlike status for Hong (as the literalists had argued), but that it stripped Jesus of his divinity and made him nothing more than a human - albeit the greatest - messenger of God.${ }^{15}$ For most of the missionaries working in China, this non-divine Jesus would have lost not only his identity as the second member of the Trinity, but also his ability to offer the necessary sacrifice (a fully divine and fully human being) to reconcile God and humankind. This key observation shows that the literal and figurative interpretations took alternative routes to reach the same conclusion that Hong's claim to be the second son of God was Christologically and soteriologically heterodox. Both confirmed, in other words, that Hong and the Taipings were not followers of 'authentic' Christianity.

Despite supporting the same conclusion as the literalists, the figurative critique provided a more accurate representation of Taiping beliefs about Jesus and Hong. The Taipings, as Edkins and John explained, believed that neither Jesus nor Hong was God - the Heavenly Father was the sole divine being in the Taipings' theology. However, the idea that the Taipings simply saw Jesus and Hong as human messengers of God (rather than actual sons of God) is inconsistent with the descriptions of an intimate heavenly family in Taiping texts. The analysis of the following section will show that whilst the Taipings did not accept the divinity of Jesus, they still believed that he and his younger brother Hong were the natural (as opposed to adopted) sons of God. 


\section{Taiping Monotheism: 'The Heavenly Father Alone Is the One True God'}

Drawing on a selection of original documents (including Hong's annotations to the Bible), this section will discuss the Taipings' doctrine of God and their specific ideas on the relation of Jesus and Hong to the deity. Whereas the Protestant missionaries assumed that Hong was either deifying himself (the literal interpretation) or denying Jesus' identity as the natural son of God (the figurative interpretation), the analysis of this section will confirm that he viewed Jesus and himself as literal but non-divine sons of God. The Heavenly Father was the sole divine being, but the sons that he sent to earth were still his natural children.

The Heavenly Father Shangdi, according to the Taipings, was a universal and allpowerful deity who created the world, sustained its life forms and controlled its natural phenomena. The Taipings explicitly discussed the unitary nature of this omnipotent God in several of their official books. In his proclamation of December 1851, which was subsequently published in the Book of Heavenly Decrees and Proclamations (Tianming zhaozhi shu; 1852), Hong asserted that the Heavenly Father alone was God (Shen):

Only the Heavenly Father, the Supreme Lord and Great Shangdi, is the true God. Besides the Heavenly Father, the Supreme Lord and Great Shangdi, all others are non-divine. The Heavenly Father, the Supreme Lord and Great Shangdi, is omniscient, omnipotent, and omnipresent. ${ }^{16}$

The Taiping Songs on World Salvation (Taiping jiushi ge; 1853) also underlined the Heavenly Father's exclusive status as God: 'Now, heaven, earth, and all things have been created by our Heavenly Father. Thus, the Heavenly Father alone is the one true God, and there is none more honourable than him.' ${ }^{17}$ Again, the Book on the Principles of the Heavenly Nature (Tianqing daoli shu; 1854) instructed its readers to 'recognise truly that the Heavenly Father, the Supreme Lord and Great Shangdi, alone is the one true God.' The book also repeated Hong's earlier claim that 'besides the Heavenly Father, the Supreme Lord and Great Shangdi, all others are non-divine. ${ }^{18}$ The Taipings' official publications, as these various 
extracts show, unambiguously stated that the Heavenly Father alone was God (Shen) and that all other beings were 'non-divine' (feishen) in nature. These claims clearly suggest that the Taipings saw neither Jesus nor Hong as God. If Hong did believe that Jesus was divine, then he would surely have added his name to the various statements that described the Heavenly Father alone as God.

The Taipings believed that their unitary God, the Heavenly Father Shangdi, had two sons: Jesus Christ and Hong Xiuquan. The Taiping Heavenly Chronicle (Taiping tianri; 1848) implied that Hong was the second son of God by calling him the 'true ordained Son of Heaven' (zhenming Tianzi) and the 'natural younger brother' (baodi) of Jesus. ${ }^{19}$ Other books were more explicit in discussing Hong's identity as a son of God. Focusing on the birth order of God's sons, the Taiping Songs on World Salvation explained that 'the Heavenly Elder Brother is our Heavenly Father's first-born son [Crown Prince], and the Heavenly King is our Heavenly Father's second son. ${ }^{20}$ Taiping publications emphasised Jesus' precedence as the first-born son of God not only through the titles Heavenly Elder Brother (Tianxiong) and Crown Prince (Taizi), but also through the more common and homely appellation of 'elder brother' $(\mathrm{ge})^{21}$ Hong's precise status as the second son of God was also underlined by the Taiping court historian Huang Zaixing, who used the designation cizi ('second son') to describe his filial relation to the Heavenly Father. ${ }^{22}$ These various titles suggested that the relation of Jesus and Hong to God was qualitatively different to that of all other human beings who had received their souls from - and thus qualified as spiritual children of - the Heavenly Father. Jesus and Hong were literal sons of God who enjoyed an intimacy with the Heavenly Father that was experienced by no other human being on earth.

In order to demonstrate further the uniqueness of his and Jesus' bond with God, Hong asserted in his annotations to the New Testament that they (along with the Eastern King Yang Xiuqing) had been specially created by the Heavenly Father and the Heavenly Mother 
(Tianmu) before the world and other human beings existed. ${ }^{23}$ As Hong put it, 'The Elder Brother, myself, and the Eastern King were originally born out of the belly of the Heavenly Father Shangdi's first wife (that is, the Heavenly Mother) before heaven and earth existed.'24 Hong, as these notes confirm, believed that he and Jesus were the natural and original sons of God and not merely the recipients of divine messages or missions. The specific claim that he and Jesus were originally born from the 'belly' (duchang) of God's wife vividly expressed the literal nature of that father-son relationship. Hong did not, however, use the narrative of his and Jesus' original creation to prove that they were fully divine members of the Godhead. Hong's intention was to demonstrate not that he and Jesus were divine or equal in status to the Heavenly Father Shangdi, but simply that they were distinct from and higher than all other human beings in the world.

Hong's discourses on the divine titles reveal one of the principal ways in which he impressed on his followers the distinction between God and his sons. Those discourses, by prohibiting the application of certain titles to Jesus and Hong, underlined Hong's core belief that the Heavenly Father alone was God. Shangdi, the translated name of God in the Chinese Christian literature, was the first title that Hong restricted to the Heavenly Father. In his proclamation of December 1851, Hong declared that 'besides the Heavenly Father, the Supreme Lord and Great Shangdi, there is no one who can usurp the title "Supreme" [Shang] or usurp the title “God” [Di].' Hong thus announced that all Taiping soldiers and officers would henceforth address him as Lord (Zhu) and not Supreme, so as to avoid offending the Heavenly Father. ${ }^{25} \mathrm{He}$ also asserted in one of his pre-rebellion texts (Exhortation on the Origin of the Way and the Enlightening of the Age (Yuandao jueshi xun; 1845-7); hereafter Second Exhortation) that the prohibition on using the divine title Shangdi extended to his elder brother Jesus. After explicitly stating (on the previous page) that 'besides the Great 
Shangdi there is no other God', Hong explained that Jesus - like him - could only be addressed as Lord:

Even Jesus the Saviour, the first-born son of the Great Shangdi, is only called our Lord. In heaven above and on earth below, among people, who is greater than Jesus? Jesus still cannot be called God [Di]. Who then dares to assume the designation of God? ${ }^{26}$

This passage implied that the Chinese emperor, who used the character $d i$ in his official title huangdi, had blasphemously usurped the position of God. ${ }^{27}$ It also suggested, on a theological level, that Hong saw neither Jesus nor himself as a divine being. Nobody on earth was higher than Jesus, but even he could not assume the name and status of God.

The Taipings' denial of Jesus' divinity was not only implied in their discourses on the titles of God. In his annotations to the New Testament, Hong (probably in response to Protestant missionaries' attempts to correct his theological views) explicitly and repeatedly stated that the Heavenly Father alone was God and that the Heavenly Elder Brother was an entirely separate non-divine being. ${ }^{28}$ On Jesus' explanation of the two great commandments (Mark 12:28-34), Hong commented, 'The Elder Brother clearly proclaims that there is only one Great Lord. Why did later disciples mistakenly explain that Christ was Shangdi? To believe their explanation is to have two Gods. ${ }^{29}$ Again, Hong wrote in his annotations to Romans 1:4 that 'Christ is Shangdi's son, and not Shangdi. ${ }^{, 30}$ He also dismissed the doctrine of the incarnation (God becoming a human being in Jesus) in his comments on Luke 1:34-5, claiming that the meaning of the passage was that 'the Holy God Shangdi came down to her [that is, Mary]' and not that 'the Holy God Shangdi entered her belly, was conceived, and became a man. ${ }^{31}$ Hong thus believed that although Jesus was the literal and natural son of Shangdi, he was not a direct incarnation of God. The idea that one divine substance was manifested in both the Father and the Son was not accepted by the Taipings. According to Hong's annotations to Mark 12:28-34, the doctrine conflicted with the truth of God's absolute oneness and created a second deity in Jesus. 
Despite denying the divinity of Jesus, Hong presented him as the greatest of all human beings and the individual with the closest connection to the Heavenly Father Shangdi. In his comments on Jesus' baptism (Mark 1:9-13), Hong claimed that the Holy God Shangdi 'dwells above the Elder Brother and leads the Elder Brother'. He also left similar notes on Mark 2:3-12: 'Shangdi dwells above the Elder Brother. Therefore, when he commanded the paralysed one, he immediately arose. ${ }^{32}$ These annotations reveal Hong's belief that God was with Jesus in a direct way on earth. The Heavenly Father not only 'dwelt above' and guided Jesus during his life, but also conferred supernatural abilities (for example, healing powers) on him. This intimacy with and ease of access to God, rather than the possession of a divine nature, set Jesus apart from all other human beings in the world. According to Hong, it was possible to assert Jesus' uniqueness in relation to humankind without making him a divine equal of the Heavenly Father.

Hong's proclamation of December 1851 further emphasised the elevated status of Jesus. Introducing another restricted term, Hong asserted that only the Heavenly Father and the Heavenly Elder Brother could be addressed as 'holy' (sheng). As Hong explained,

The Heavenly Father is the Holy Heavenly Father, and the Heavenly Elder Brother is the Holy Saviour. The Heavenly Father and the Heavenly Elder Brother alone are holy. Henceforth, all soldiers and officers may address me as Lord, and that is all. It is not appropriate to call me Holy, lest you offend the Heavenly Father and the Heavenly Elder Brother. ${ }^{33}$

This discussion on the holiness of God and his first-born son suggested not only that Jesus was higher than all human beings outside the heavenly family, but also that he occupied a more prominent position in the family than his younger brother Hong (who was prohibited from using the designation sheng). The Taipings firmly denied the idea that Jesus was God, but Hong's deferential attitude towards his elder brother confirms that they regarded him as the greatest of all non-divine (feishen) beings. 


\section{God, Jesus and Hong: The Roots of the Heavenly Hierarchy}

The Taipings' religious publications put forward a radically original and highly monotheistic doctrine of God. The Heavenly Father Shangdi was, they believed, the one true God (Shen). Jesus and Hong were the natural sons of God, and Jesus - as the Crown Prince and Heavenly Elder Brother - was the most holy and honourable person ever to have appeared on earth. Despite granting Jesus that elevated status, the Taipings categorically rejected the idea that he was a divine equal of the Heavenly Father. This section will examine why exactly the Taipings adopted this highly monotheistic doctrine that acknowledged the divinity of the Heavenly Father alone. The analysis will reveal that the Taipings' doctrine of God was a response not only to terms and themes from the translated biblical text, but also to theological priorities that were determined by Hong's soteriological vision and its interpretation of China's religious history.

Hong, in response to the translated name of God (Shangdi) in Liang's Good Words and the Chinese Bible, declared that his soteriological mission was to exterminate the demons and restore the classical deity of China, Shangdi. ${ }^{34}$ That core belief, which was the foundation of Hong's new theological worldview, not only enabled the Taipings to emphasise the 'Chinese' (as opposed to entirely foreign) character of their Christian God, but also encouraged them to view that God as an independent and unitary deity. The classical Shangdi was not the Trinitarian God who existed as Father, Son and Holy Spirit, but a singular deity who acted as the 'ruler of the people below'. ${ }^{35}$ As the ruling deity, Shangdi 'conferred on the people a moral sense', rewarded their good deeds with numerous blessings and punished their acts of evil with all kinds of calamities. ${ }^{36}$ Shangdi also nourished human life and, as the provider of the Heavenly Mandate (Tianming), appointed and removed the various rulers of the world. ${ }^{37}$ Although the Taipings' religious publications contained only a few explicit references to the classics, their descriptions of God's activities in the world (universal ruler, 
nourisher of humankind, provider of blessings, punisher of evil, appointer of kings) show that the central characteristics of their deity reflected those of the classical Shangdi no less than those of the biblical Father. ${ }^{38}$ The reason for this functional overlap was the Taipings' discourse that they were restoring the Chinese people's ancient worship of God. If that discourse was to have any credibility, then the Taipings' new Christian God would have to take on some of the core attributes (including, most importantly, absolute oneness) of the ancient and classical Shangdi. The Taipings' restorationist vision of world salvation inclined them, in short, to view Shangdi/Shen (the terms used by missionaries and Liang to designate the Trinitarian God) as a singular deity consisting of the Heavenly Father alone.

The Taipings' vision of world salvation also declared that the sources of China's spiritual ignorance were demonic idols and false gods (especially those of Buddhism and Daoism) that had usurped the position of Shangdi historically. ${ }^{39}$ That conviction allowed the Taipings to depict Hong as the divinely ordained slayer of demons, but at the same time it predisposed them to view both Jesus and Hong as non-divine beings. The Taipings believed that elevating either Jesus or Hong to the level of God would have contradicted the claim that they were destroying the usurpers of Shangdi's position in China, showing that they were actually guilty of the same crime as their demonic adversaries. Confirmation of this link between the Taipings' soteriological vision and their denial of Jesus' divinity can be found in one of Hong's pre-rebellion texts, the Second Exhortation. Before stating that Jesus was to be addressed as Lord (Zhu) and not God (Di), Hong referred to the 'idols' (ouxiang) of China that had taken the place of Shangdi for approximately two thousand years:

As for all those nameless and poison-swollen ones [idols], they are all demonic followers and devilish servants of the square-headed and red-eyed Serpent Devil, the Demon of Hades. From Qin and Han [221 BCE-220 CE] down to the present, a period of one or two thousand years, how many people's souls have been captured and destroyed by this Demon of Hades. ${ }^{40}$ 
The proximity of this extract on the history of demonic usurpers to a statement prohibiting the application of the title Di to Jesus confirms that the Taipings' vision of world salvation was the theological basis for their denial of Jesus' divinity. Hong, a religious leader whose revolutionary mission was to overthrow the usurpers of God's position in China, would have lost all credibility if he had proclaimed himself or any other being an equal of Shangdi. Doing so would have revealed not his exalted status and spiritual authority, but that he had fallen into the same self-glorifying trap as the idols and popular deities that had wrongfully taken the place of God for two thousand years.

The Taipings' vision of world salvation, which associated the Christian God with the classical deity and condemned the demons that had usurped his position historically, was the principal factor behind their monotheistic conception of God. Another major source of inspiration for the Taipings' theological doctrine was the third commandment, which was recorded by the Taipings in the Book of Heavenly Commandments (Tiantiao shu; 1852): 'Do not take the name of the Great Shangdi in vain. The name of the Great Shangdi is Jehovah [Yehuohua], which people must not take in vain. ${ }^{41}$ Although the Chinese Bible's explanation of the third commandment (Exodus 20:7) only mentioned the divine title Shangdi, Liang's Good Words had frequently referred to the Christian deity as God Jehovah (Shen Yehuohua). ${ }^{42}$ Those many references to the Hebrew name of God in Liang's work explain why the Taipings' record of the third commandment prohibited the misuse of both Shangdi and Jehovah.

Evidence of the third commandment's influence on the Taipings' thinking about God is not restricted to the Book of Heavenly Commandments. The Taipings' pre-rebellion writings had, in fact, already asserted that the divine titles Shangdi and Jehovah belonged to the Heavenly Father alone. ${ }^{43}$ They also offered typical examples of blasphemies against those titles. On the first title Shangdi, Hong's Second Exhortation claimed, 
When Hui of Song [r. 1100-26] appeared, he changed the appellation of the Great Shangdi to the Great Jade Emperor, God of the Golden Palace of the Luminous Heaven... to call him the Great Jade Emperor is indeed the worst kind of blasphemy against the Great Shangdi. ${ }^{44}$

Hong thus believed that using the character $d i$, as the Daoist Jade Emperor (Yuhuang Dadi) had done, was a blasphemy against the name of God, Shangdi. That belief, which stemmed from Hong's reading of the third commandment, not only inspired his early critique of the imperial office, but also lay behind his formal announcement (in the Second Exhortation and the proclamation of December 1851) that neither he nor Jesus could be addressed as God. The biblical prohibition on misusing the divine title Shangdi contributed, in other words, to the monotheistic doctrine that denied the divinity of Jesus. The prohibition reinforced Hong's belief, based on his soteriological vision, that the Heavenly Father alone was God and that his unique status had to be constantly protected against the threat of usurpers.

The Taipings' vision of world salvation and the third commandment both contributed to their highly monotheistic conception of God. Those sources of inspiration for the Taipings' monotheistic perspective do not, however, explain the most unique feature of their doctrine of God, namely, the hierarchical relationship between the Heavenly Father, Jesus and Hong. Discourses on the various divine titles (for example, Supreme (Shang) and God (Di)) highlighted the pre-eminent position of the Heavenly Father among the three. The claim that only he and Jesus could be addressed as holy (sheng) revealed, furthermore, the superior status of the Heavenly Elder Brother over his younger sibling Hong. This hierarchical ordering of the Heavenly Father, the Heavenly Elder Brother and the Heavenly King was also expressed by the Taipings on the pages of their religious publications. Whereas Protestant missionaries saw no issue in placing the names of the Heavenly Father and Jesus on the same level (as they were equal members of the Godhead in their theology), the Taipings believed that such writing practices blurred the essential distinction in status between the two. Thus, whenever the names of God, Jesus and Hong appeared in an official Taiping document, the 
scribe would start a new line that was raised (Chinese scribes, unlike those of Western countries, wrote vertically) three levels above the main text in the case of the Heavenly Father, two levels in the case of Jesus and one level in the case of Hong. This alternative, status-affirming practice of raising official titles was derived from an imperial custom. In order to demonstrate their loyalty to the ruling emperor, memorialists would place his reign name clearly above the main text and the names of other significant officials. ${ }^{45}$ The key difference between such memorials and the books of the Taipings is that the latter used the technique of raising names to emphasise not only the exalted status of the ruler, but also the duty of the people to acknowledge and obey a spiritual being whose authority exceeded that of earthly kings.

The construction of a heavenly hierarchy (Father, Elder Brother and King) shows that Hong interpreted God's relation to his sons through the Confucian doctrine of the five relationships (wulun). That doctrine, one of the basic components of China's Confucian ethical orthodoxy, taught that social order was maintained when (1) ministers loyally served their sovereign, (2) sons revered their fathers, (3) younger brothers respected their elder brothers, (4) wives obeyed their husbands and (5) friends were mutually faithful. ${ }^{46}$ These various relationships, with the exception of the fifth, promoted a social system that was characterised by age- and gender-based status distinctions. The application of this sociopolitical doctrine to a theological issue might appear strange on the surface, but we need to remember that the Chinese Bible and Liang's Good Words presented God and Jesus to the Taipings not as abstract spiritual entities, but in the familiar language of 'father' $(f u)$ and 'son' $(z i)$. Hong's identity as a son of God thus brought him into a filial relationship with the Heavenly Father and a fraternal relationship with Jesus (his Heavenly Elder Brother, Tianxiong). Embracing the maxim of the Classic of Filial Piety (Xiao jing) that all 'sons' (zi) should revere their 'fathers' $(f u)$ and all 'younger brothers' $(d i)$ should respect their 'elder 
brothers' (xiong), Hong depicted the Heavenly Father as the supreme and most dignified member of the heavenly family and his eldest son Jesus as the Crown Prince and highest in rank of all his children (and all other non-divine beings by extension) ${ }^{47}$ Hong, in other words, acknowledged the superiority of both the Heavenly Father and the Heavenly Elder Brother over himself. The idea that a son could be the equal of his father (or a younger brother the equal of his elder brother) was, from Hong's Confucianised perspective, a violation of proper relationships.

\section{Taipings and Missionaries: Different Theological Priorities}

The analysis of this paper has shown that Hong's claim to be the second son of God provides an access point for understanding the Taipings' localised theology. Hong was not - as many of the Protestant missionaries in China believed - incorporating himself into the Godhead, but simply affirming that he was the natural son of the Heavenly Father Shangdi. The Heavenly Father, Hong insisted, was the sole divine being and the exclusive holder of the title Shangdi. This highly monotheistic doctrine of God highlights the different theological priorities of the Taipings and their missionary critics. The Taipings' main priority, which stemmed from Hong's classically inspired vision of world salvation, was to protect the oneness and uniqueness of the Heavenly Father Shangdi, as opposed to the divinity of Jesus or the triune nature of the Godhead. Their discourse on the history of idols and false gods usurping Shangdi's position in China made them extremely sensitive to the possibility of individuals (religious and political) falsely assuming the identity and titles of God. That sensitivity manifested itself not only in the Taipings' conviction that the Chinese emperor was a usurper of God's title (Di), but also in their belief that Jesus was a non-divine being who was ontologically distinct from the Heavenly Father. Hong's soteriological vision (reinforced by the third commandment) compelled him, in short, to deny the idea that he and 
Jesus, as sons of God, were divine. This observation shows that we can only fully understand the Taipings' beliefs about God and his sons if we analyse them within the Taipings' wider theological worldview. Disconnecting those beliefs from that worldview and analysing them through an external standard of orthodoxy leads only to essentialist judgements (heterodox, blasphemous, pseudo-Christian) that conceal the complex theological considerations from which the Taipings' localised doctrine of God emerged.

The Taipings' lack of commitment to the alien orthodoxy of the missionaries facilitated not only their highly monotheistic doctrine of God, but also their new interpretation of God's relation to his sons. According to the Taipings, the Heavenly Father was the sole divine being and thus superior in status to his two sons, Jesus and Hong. The Taipings expressed that superiority not only by reserving specific titles for the Heavenly Father, but also by elevating his name above those of Jesus and Hong in their official publications. The relationship of Jesus and Hong was similarly characterised by status distinction, with the Heavenly Elder Brother - as the Crown Prince (Taizi) and the only nondivine person allowed to be addressed as holy (sheng) - occupying a more prominent position in the heavenly family than his younger sibling Hong. This hierarchical classification of God and his two sons highlights, as the final part of this paper suggested, the localisation of Christian symbols (namely, the Father and Jesus) via the Confucian doctrine of the five relationships, which determined the relative status and duties of individuals within the family according to their age and gender. The Chinese Bible and Liang's Good Words had provided the terminological triggers ( $f u$, 'father'; $z i$, 'son') for that localised interpretation of God's relation to his sons, but it could only have emerged in a world that acknowledged a truth greater than the doctrine that three equal divine persons constitute one God. The Taiping Heavenly Kingdom, founded on the revelations of Hong and his mission to restore the God of ancient China, was one such world. 
The theology of Yang Tingyun (1557-1627), a Confucian scholar who converted to Christianity in the early seventeenth century, shows that Hong was not the first Chinese Christian to construct a Confucianised doctrine of God. Yang's theology was a direct response to the claim of Matteo Ricci (1552-1610) that the Christian God was synonymous with the classical deity Shangdi. Like Hong, Yang asserted that his newfound God was the deity of ancient China and condemned Buddhism and Daoism for distorting the Chinese people's consciousness of God/Heaven. ${ }^{48}$ Yang's religious writings also stressed that God was an omnipotent Lord who created the universe and acted as the Great Father-Mother (Dafumu) of humankind. ${ }^{49}$ These ideas highlight some of the overlaps between the theologies of Yang and Hong, showing that Hong's monotheistic doctrine was not an irrational and entirely unprecedented response to the divine title Shangdi. However, the theologies of Yang and Hong are fundamentally opposed on the question of the Trinity. Despite describing the Trinity as a mysterious doctrine that one could only explain through transliterated concepts, Yang's writings show that he acknowledged both the divinity of Jesus and the triune nature of the Godhead. ${ }^{50}$ Yang's acceptance of these orthodox ideas confirms, among other things, the theological significance of Hong's disconnection from the missionary community. ${ }^{51}$ Yang and Hong (as classically trained scholars) would have experienced similar doubts regarding the Trinity, but Hong alone was free to reject the orthodox tradition and the specific idea that the classical deity consisted of three persons.

Finally, the analysis of this paper suggests that abandoning Christian essentialism can enhance our understanding of the relationship between language and culture, or vernacularisation and localisation, in the era of global Protestant missions. By carefully analysing the meaning of Hong's title, rather than dismissing it as evidence of heterodoxy or theological corruption, this paper has identified a new localised doctrine of God that was shaped by concepts and values from the Chinese classics. Significantly, that localised 
theology was not a random product of Hong's 'heterodox' mind, but a response to terms from the Chinese Christian literature (Shangdi, $f u, z i$ ) that connected the Christian religion to the cultural world of Confucianism. It is hardly surprising that Hong, an individual who had studied the classics from childhood, recognised and developed those text-world overlaps in his new theology. Nor is it surprising that Protestant missionaries, who believed that they were transmitting a universal form of Christianity to China, overlooked those overlaps in their discussions of Hong's beliefs. Recognising them would not only have challenged the missionaries' views about the universality of orthodoxy, but would also have suggested that their work in translating Christian texts was partly responsible for the emergence of Hong's 'deviant' belief system.

Carl Kilcourse is a postdoctoral researcher at the University of Manchester. His PhD thesis, which he is currently preparing for publication, examines the localisation of Christianity in the theology and religious culture of the Taipings. He is particularly interested in global Protestant missions, Chinese Christianities and the relationship between vernacularisation and localisation. Email: carlkilcourse@ hotmail.co.uk

\footnotetext{
${ }^{1}$ The date of Hong's third failure is confirmed by Theodore Hamberg (1819-54). Theodore Hamberg, The Chinese Rebel Chief, Hung-Siu-tsuen; And the Origin of the Insurrection in China (London: Walton \& Maberly, 1855), pp. 14-15.

2 'The Taiping Heavenly Chronicle' (1862 (written 1848)), in Franz Michael and Chung-li Chang (eds), The Taiping Rebellion: History and Documents, vol. 2: Documents and Comments, parts 1-4 (Seattle: University of Washington Press, 1971), 51-76; pp. 63-5. Taiping tianri (Taiping Heavenly Chronicle; 1862 [written 1848]), in Xuxiu Siku quanshu (Supplement to the Complete Collection of the Four Treasuries), vol. 445 (Shanghai: Shanghai guji chubanshe, 1995-2002), 359-77; pp. 368-9 (pp. 18-21 of original). China Academic Digital Associative Library (website). Available at http://www.cadal.zju.edu.cn/book/02011118/ (accessed 10 December 2012).

3 'The Taiping Heavenly Chronicle', p. 53. Taiping tianri, p. 360 (p. 3 of original).

4 'The Taiping Heavenly Chronicle', pp. 57-8, 62. Taiping tianri, pp. 364, 367 (pp. 10, 16-17 of original).

5 'The Taiping Heavenly Chronicle', pp. 57, 59 (original translation revised). Taiping tianri, pp. 363, 365 (pp. 9 , 12-13 of original). The Taiping Heavenly Chronicle also described Hong as the Son of Heaven (Tianzi). 'The Taiping Heavenly Chronicle', pp. 62-3. Taiping tianri, p. 367 (p. 17 of original).

${ }^{6}$ Eugene Powers Boardman, Christian Influence upon the Ideology of the Taiping Rebellion, 1851-1864 (Madison, WI: University of Wisconsin Press, 1952), p. 114. Vincent Y. C. Shih, The Taiping Ideology: Its Sources, Interpretations, and Influences (Seattle, WA: University of Washington Press, 1967), p. xvii. Christopher Munn, 'Introduction to the Paperback Edition', in Carl T. Smith, Chinese Christians: Elites, Middlemen, and the Church in Hong Kong (Hong Kong: Hong Kong University Press, 2005), ix-xxi; p. xii. Samuel Hugh Moffett, A History of Christianity in Asia, vol. 2: 1500-1900 (Maryknoll, NY: Orbis, 2005), pp. 293, 299. Joseph W. Esherick, The Origins of the Boxer Uprising (Berkeley, CA: University of California Press, 1987), p. 322. Richard R. Cook, 'Overcoming Missions Guilt: Robert Morrison, Liang Fa, and the Opium
} 
Wars', in Richard R. Cook and David W. Pao (eds), After Imperialism: Christian Identity in China and The Global Evangelical Movement (Cambridge: Lutterworth, 2012), 35-45; p. 40.

${ }^{7}$ Alexander Wylie, 'A Report by Rev. A. Wylie' (January 1859), in Prescott Clarke and J. S. Gregory (eds), Western Reports on the Taiping: A Selection of Documents (London: Croom Helm, 1982), 219-22; p. 221. Originally published in Missionary Magazine and Chronicle, vol. 23 (July 1859), 179-81.

${ }^{8}$ W. N. Hall, 'A Letter from Rev. W. N. Hall' (January-February 1861), in Clarke and Gregory (eds), Western Reports, 280-1; p. 281. Originally published in Missionary Herald, vol. 57 (September 1861), 137-8.

${ }^{9}$ Issachar Jacox Roberts, 'A Letter from Rev. I. J. Roberts [a]' (22 January 1862), in Clarke and Gregory (eds), Western Reports, 314-16; p. 314. Originally published in North China Herald, 4 February 1862.

${ }^{10}$ Josiah Cox, 'Journal of Rev. Josiah Cox' (December 1861), in Clarke and Gregory (eds), Western Reports, 308-14; pp. 311-12. Originally published in Wesleyan Missionary Notices, 3rd series, vol. 9 (25 April 1862), 6972.

11 These orthodox assumptions about Jesus' soteriological role were based on the Anselmian theory of atonement. See Anselm, 'Why God Became a Man (Cur Deus Homo)', in Jasper Hopkins and Herbert Richardson (eds), Anselm of Canterbury, vol. 3 (New York: Edwin Mellen, 1976), 49-137.

12 Joseph Edkins, 'A Report by Rev. Joseph Edkins' (1860), in Clarke and Gregory (eds), Western Reports, 2416; p. 241. Originally published in North China Herald, 11 August 1860.

${ }^{13}$ Griffith John, 'A Letter from Rev. Griffith John' (16 July 1860), in Clarke and Gregory (eds), Western Reports, 231-7; p. 235. Originally published in Missionary Magazine and Chronicle, vol. 24 (October 1860), $270-5$.

${ }^{14}$ John Hobson, ‘A Letter from Rev. John Hobson' (18 May 1861), in Clarke and Gregory (eds), Western Reports, 298. Original document obtained from the Archives of the Church Missionary Society, China Letters (Box H-R). E. G. Fishbourne, Impressions of China and the Present Revolution: Its Progress and Prospects (London: Seeley, Jackson, and Halliday, 1855), p. 262.

${ }^{15}$ It is for this reason that Edkins associated the Taipings with the heresy of Arianism. Joseph Edkins, 'Narrative of a Visit to Nanking', in Jane R. Edkins, Chinese Scenes and People: With Notices of Christian Missions and Missionary Life in a Series of Letters from Various Parts of China (London: James Nisbet \& Co., 1863), 241307 ; p. 279.

16 'The Book of Heavenly Decrees and Proclamations' (1852), in Michael and Chang (eds), The Taiping Rebellion, vol. 2, 97-110; pp. 107-8 (original translation revised). Tianming zhaozhi shu (Book of Heavenly Decrees and Proclamations; 1852), p. 11. National Library of Australia (website). Available at http://nla.gov.au/nla.gen-vn2032025 (accessed 21 October 2010).

17 'Taiping Songs on World Salvation' (1853), in Michael and Chang (eds), The Taiping Rebellion, vol. 2, 237 50; p. 239 (original translation revised). Taiping jiushi ge (Taiping Songs on World Salvation; 1853), p. 1. National Library of Australia (website). Available at http://nla.gov.au/nla.gen-vn2033672 (accessed 21 October 2010).

18 'The Book on the Principles of the Heavenly Nature' (1854), in Michael and Chang (eds), The Taiping Rebellion, vol. 2, 364-408; p. 369 (original translations revised). Tianqing daoli shu (Book on the Principles of the Heavenly Nature; 1854), p. 4. New York Public Library (website). Available at http://digitalgallery.nypl.org/nypldigital/id?1707517 (accessed 22 October 2010).

19 'The Taiping Heavenly Chronicle', pp. 57, 62 (original translation revised). Taiping tianri, pp. 363, 367 (pp. 9,17 of original).

20 'Taiping Songs on World Salvation', p. 242 (original translation revised). Taiping jiushi ge, p. 4.

21 'The Taiping Heavenly Chronicle', p. 61. Taiping tianri, p. 366 (p. 14 of original).

22 'Treatises on Affixing the Imperial Seal on Proclamations and Books for Publication' (1853), in Michael and Chang (eds), The Taiping Rebellion, vol. 2, 295-308; p. 305. Zhaoshu gaixi banxing lun (Treatises on Affixing the Imperial Seal on Proclamations and Books for Publication; 1853), p. 10. New York Public Library (website). Available at: http://digitalgallery.nypl.org/nypldigital/id?1706830 (accessed 22 October 2010).

${ }^{23}$ The inclusion of Yang in the narrative relates to both his religious role (charismatic communicator for the Heavenly Father) and political rise within the Taiping Heavenly Kingdom.

24 'Hong Xiuquan's Annotations to the New Testament', in Michael and Chang (eds), The Taiping Rebellion, vol. 2, 226-37; p. 236 (original translation revised). Qinding qian yizhao shengshu (Authorised Taiping New Testament, with Hong Xiuquan's Annotations); cited in Luo Ergang, Taiping Tianguo shi (di'er ce) (The History of the Taiping Heavenly Kingdom, vol. 2) (Beijing: Zhonghua shuju, 1991), p. 692.

25 'The Book of Heavenly Decrees and Proclamations', p. 108 (original translation revised). Tianming zhaozhi shu, p. 11.

26 'The Taiping Imperial Declaration' (1852), in Michael and Chang (eds), The Taiping Rebellion, vol. 2, 24-47; pp. 45-6 (original translations revised). Taiping zhaoshu (Taiping Imperial Declaration; 1852), pp. 17-18. 
National Library of Australia (website). Available at http://nla.gov.au/nla.gen-vn511334 (accessed 21 October 2010).

${ }^{27}$ For a discussion of this blasphemy and its contribution to Hong's revolutionary thought, see Thomas H.

Reilly, The Taiping Heavenly Kingdom: Rebellion and the Blasphemy of Empire (Seattle: University of

Washington Press, 2004).

${ }^{28}$ One of Issachar Roberts' reports confirms that he, at an official meeting in November 1860, 'endeavoured to improve' Hong's theological views. Joseph Edkins also attempted to correct Hong's opinions through religious writings. During a visit to Nanjing in early 1861, Edkins handed his papers on the divinity of Jesus to a young Taiping chief. Issachar Jacox Roberts, 'A Letter from Rev. I. J. Roberts [b]' (13 November 1860), in Clarke and Gregory (eds), Western Reports, 254-5; p. 255. Originally published in Overland China Mail, 15 December 1860. Edkins, 'Narrative of a Visit to Nanking', pp. 267-8.

29 'Hong Xiuquan's Annotations to the New Testament', p. 229 (original translation revised). Qinding qian yizhao shengshu; cited in Luo, Taiping Tianguo shi (di'er ce), pp. 696-7.

30 'Hong Xiuquan's Annotations to the New Testament', p. 231 (original translation revised). Qinding qian yizhao shengshu; cited in Luo, Taiping Tianguo shi (di'er ce), p. 698.

31 'Hong Xiuquan's Annotations to the New Testament', p. 230 (original translation revised). Qinding qian yizhao shengshu; cited in Luo, Taiping Tianguo shi (di'er ce), p. 697.

32 'Hong Xiuquan's Annotations to the New Testament', p. 229 (original translation revised). Qinding qian yizhao shengshu; cited in Luo, Taiping Tianguo shi (di'er ce), pp. 699, 701.

33 'The Book of Heavenly Decrees and Proclamations', p. 108 (original translation revised). Tianming zhaozhi shu, pp. 11-12.

${ }^{34}$ Robert Morrison (1782-1834) had originally translated God as Shen ('God' or 'Spirit'), but the later Gützlaff translation of the Bible (which Hong received in 1847) used the classical term Shangdi as the Chinese name for God. Liang's Good Words followed the Morrison-Milne Bible in using Shen, but it also employed the extended title Shentian Shangdi ('God of Heaven Shangdi') in many of its references to the Christian deity.

${ }^{35}$ James Legge (trans.), Shijing (Book of Odes), Greater Odes of the Kingdom: Decade of Dang, Dang (original translation revised). Chinese Text Project (website). Available at http://ctext.org/book-of-poetry (accessed 13 August 2011).

${ }^{36}$ James Legge (trans.), Shangshu (Book of History), Shang Shu: Announcement of Tang (original translation revised). Chinese Text Project (website). Available at http://ctext.org/shang-shu (accessed 13 August 2011). Shangshu, Shang Shu: Instructions of Yi.

${ }^{37}$ On nourishment: Shijing, Odes of the Temple and the Altar: Decade of Chen Gong, Chen Gong. The Book of History and the Book of Odes both discussed the political function of God, using the examples of Wen and Wu to show that Shangdi rewarded righteous kings with the mandate to rule. Shangshu, Zhou Shu: Announcement of King Kang. Shijing, Greater Odes of the Kingdom: Decade of Wen Wang, Da Ming.

38 'The Taiping Imperial Declaration', pp. 35, 40-1. Taiping zhaoshu, pp. 9, 12-13. 'The Taiping Heavenly Chronicle', pp. 59, 62. Taiping tianri, pp. 365, 367 (pp. 12-13, 17 of original).

${ }^{39}$ For Hong's condemnation of Daoist 'immortals' (shenxian) and Buddhist 'idols' (ouxiang), see 'The Taiping Imperial Declaration', pp. 42-4. Taiping zhaoshu, pp. 15-16.

40 'The Taiping Imperial Declaration', p. 46 (original translation revised). Taiping zhaoshu, p. 18.

41 'The Book of Heavenly Commandments' (1852), in Michael and Chang (eds), The Taiping Rebellion, vol. 2, 111-24; p. 120 (original translation revised). Tiantiao shu (Book of Heavenly Commandments; 1852), p. 7. National Library of Australia (website). Available at http://nla.gov.au/ nla.gen-vn2032067 (accessed: 21 October 2010).

42 Jiu yizhao shengshu (The Old Testament (Genesis, Exodus, Numbers); 1853), Exodus, p. 31. National Library of Australia (website). Available at http://nla.gov.au/nla.gen-vn2033774 (accessed: 23 October 2010). For one of many examples of Liang using the title God Jehovah, see Liang Fa, Quanshi liangyan (Good Words to Admonish the Age; 1832) (Taibei: Taiwan xuesheng shuju, 1965), volume 1, p. 17.

${ }^{43}$ For evidence of Hong's anxiety to protect the title Jehovah (Yehuohua), see 'The Taiping Heavenly Chronicle', pp. 59-60. Taiping tianri, p. 365 (p. 13 of original). 'The Book of Heavenly Decrees and Proclamations', p. 108. Tianming zhaozhi shu, p. 12.

44 'The Taiping Imperial Declaration', p. 44 (original translation revised). Taiping zhaoshu, p. 16.

${ }^{45}$ Evelyn S. Rawski, The Last Emperors: A Social History of Qing Imperial Institutions (Berkeley, CA: University of California Press, 1998), p. 49.

${ }^{46}$ The five relationships are discussed in the Doctrine of the Mean and the Mencius. James Legge (trans.), Liji (Book of Rites), Zhong Yong: 20. Chinese Text Project (website). Available at http://ctext.org/liji (accessed: 3 June 2011). James Legge (trans.), Mengzi (Mencius), Teng Wen Gong 1: 4. Chinese Text Project (website). Available at http://ctext.org/mengzi (accessed: 4 April 2012). 
${ }^{47}$ James Legge (trans.), Xiao jing (Classic of Filial Piety), Amplification of 'The All-embracing Rule of Conduct' in Chapter 1. Chinese Text Project (website). Available at http://ctext.org/xiao-jing (accessed 13 October 2011).

${ }^{48}$ N. Standaert, Yang Tingyun, Confucian and Christian in Late Ming China: His Life and Thought (Leiden: E. J. Brill, 1988), pp. 127-8, 130-1.

${ }^{49}$ Standaert, Yang Tingyun, pp. 109, 116-18.

${ }^{50}$ Standaert, Yang Tingyun, pp. 123-6, 129-30.

${ }^{51}$ Following a two-month stay with Issachar Roberts in 1847, Hong was able to develop his theology without any guidance from missionaries. 